\title{
ALTERATIONS ON PHENOLIC COMPOUNDS AND ANTIOXIDANT ACTIVITY DURING SOUR GRAPE JUICE CONCENTRATE PROCESSING
}

\section{ALTERAÇÕES DOS COMPOSTOS FENÓLICOS E DA ATIVIDADE ANTIOXIDANTE DURANTE O PROCESSO DE CONCENTRAÇÃO DE SUMO DE UVAS NÃO AMADURECIDAS}

\author{
Ali Guler ${ }^{*}$, Ozlem Tokusoglu², Nevzat Artik ${ }^{3}$ \\ ${ }^{1}$ Viticulture Research Institute, Atatürk Strt, Horozköy Ave., 45125 Yunusemre/Manisa, Turkey. \\ ${ }^{2}$ Celal Bayar University, Engineering Faculty, Department of Food Eng., 45140, Manisa, Turkey. \\ ${ }^{3}$ Ankara University, Engineering Faculty, Department of Food Eng., Ankara, Turkey. \\ * Corresponding author: Tel: +902362111071, e-mail: aligguler@gmail.com
}

(Received 13.08.2018. Accepted 04.10.2018)

\section{SUMMARY}

The alterations of phenolic compounds and antioxidant capacity of sour grape juice were investigated during the concentration process stages. Phenolics and antioxidant properties of the samples changed more at the vacuum evaporation stage than that of the other stages. After evaporation, the antioxidant capacity of the samples decreased approximately between 14.2 and $17.0 \%$ for DPPH and ABTS methods, respectively. Besides, phenolic contents also decreased approximately as $14.8 \%$. HPLC data on phenolics of sour grape juice during concentrate processing gave 12 polyphenols, including gallic acid, (+)-catechin, (-)-epigallocatechin, vanillic acid, (-)-epigallocatechin gallate, (-)-epicatechin, caftaric acid, caffeic acid and $p$-coumaric acid, which were determined as $1.05-1.83 \mathrm{mg} / 100 \mathrm{~g}, 5.40-7.83 \mathrm{mg} / 100 \mathrm{~g}, 6.35-9.21 \mathrm{mg} / 100 \mathrm{~g}, 3.01-5.18 \mathrm{mg} / 100 \mathrm{~g}, 0$ $1.95 \mathrm{mg} / 100 \mathrm{~g}, 2.33-3.54 \mathrm{mg} / 100 \mathrm{~g}, 12.40-37.60 \mathrm{mg} / 100 \mathrm{~g}, 1.44-2.26 \mathrm{mg} / 100 \mathrm{~g}$ and $0.27-0.44 \mathrm{mg} / 100 \mathrm{~g}$, respectively. Ferulic, sinapic acids and quercetin were only detected at concentrate step of the sour grape juice processing and were found as $0.18 \mathrm{mg} / 100 \mathrm{~g}, 0.28 \mathrm{mg} / 100 \mathrm{~g}$ and 0.76 $\mathrm{mg} / 100 \mathrm{~g}$, respectively.

\section{RESUMO}

As alterações dos compostos fenólicos e da capacidade antioxidante do sumo de uvas não amadurecidas foram investigadas durante as etapas do processo de concentração. Os compostos fenólicos e as propriedades antioxidantes das amostras sofreram maior alteração na fase de evaporação sob vácuo do que nas restantes fases. Após a evaporação, a capacidade antioxidante das amostras diminuiu aproximadamente entre 14.2 e $17.0 \%$ nas determinações efetuadas pelos métodos DPPH e ABTS, respetivamente. Por outro lado, os teores de compostos fenólicos também diminuiram aproximadamente $14.8 \%$. Os resultados obtidos por HPLC revelaram a presença de 12 polifenóis, incluindo ácido gálhico, $(+)$-catequina, $(-)$ epigalhocatequina, ácido vanílico, (-)-epigalhocatequina galhato, (-)-epicatequina, ácido caftárico, ácido cafeico e ácido $p$-cumárico, com teores de $1.05-1.83 \mathrm{mg} / 100 \mathrm{~g}, 5.40-7.83 \mathrm{mg} / 100 \mathrm{~g}, 6.35-9.21 \mathrm{mg} / 100 \mathrm{~g}, 3.01-5.18 \mathrm{mg} / 100 \mathrm{~g}, 0-1.95 \mathrm{mg} / 100 \mathrm{~g}, 2.33-3.54 \mathrm{mg} / 100 \mathrm{~g}, 12.40-37.60 \mathrm{mg} / 100$ g, 1.44-2.26 mg/100 g e 0.27-0.44 mg/100 g, respetivamente. Os ácidos ferúlico e sinápico e a quercetina foram detetados somente na etapa de concentração do sumo de uvas não amadurecidas, com teores de $0.18 \mathrm{mg} / 100 \mathrm{~g}, 0.28 \mathrm{mg} / 100 \mathrm{~g}$ e $0.76 \mathrm{mg} / 100 \mathrm{~g}$, respetivamente.

Key words: sour grape juice, concentrate, processing, phenolic compounds, antioxidant activity.

Palavras-chave: sumo de uvas não amadurecidas, concentração, processamento, compostos fenólicos, atividade antioxidante.

\section{INTRODUCTION}

Fruits play important role on the protection of human health due to their contents such as phenolics, minerals, vitamins and antioxidants. Grape (Vitis sp.) is one of the most produced fruits in the world. It is used for wine, juice, raisin, sour grape juice, vinegar and pekmez (grape concentrate, molasses). Sour grape is used for 'verjuice' or sour grape juice, consuming for salad dressing, processed vegetables and drinks as sherbet with sweeteners (Karapinar and Sengun, 2007; Nickfardjam, 2008). The sour grape juice has different names, such as 'verjuice', 'verjus' and 'koruk' juice, according to the producing country. Additionally, it has been traditionally produced for many years.

This is an Open Access article distributed under the terms of the Creative Commons Attribution License (http://creativecommons.org/licenses/by/4.0), which permits unrestricted use, distribution, and reproduction in any medium, provided the original work is properly cited. 
Grape includes polyphenols that have protective effect on human health (Chira et al., 2008; Xia et al., 2010; Toaldo et al., 2015). The phytochemical polyphenols have anticancer and anti-inflammatory effects in vitro (Castilla et al., 2006; Capanoglu et al., 2013). It was reported that these compounds inhibit cardiovascular diseases, some types of cancer cells, reduce plasma oxidation stress and aging effect (Meyer et al., 1997; Falchi et al., 2006; God et al., 2007; Xia et al., 2010; Tsanga et al., 2015). Many studies were performed related to the grape, wine and grape juice effects on human health although investigations on improving health of sour grape juice were fairly limited. ZibaeeNezhad et al. (2012) expressed that sour grape juice had improving effect on serum levels of HDL-C but no lipid-lowering effect on triglyceride and serum levels of LDL-C. Grape polyphenols show high antioxidant properties. For this reason, many researchers tried to determine the relationship between phenolic compounds and antioxidant activity of the grape (Xia et al., 2010). It was stated that significant correlations were found among phenolic compounds and antioxidant activity of grape, grape juice, grape concentrate and wine (Castilla et al., 2006; Paixao et al., 2007; Stratil et al., 2008; Gollucke et al., 2009; Buyuktuncel et al., 2014; Lima et al., 2014; Toaldo et al., 2015).

No study related to sour grape juice processing and concentration could be found in literature although many studies were conducted on grape juice processing and concentration (Gollucke et al., 2009; Capanoglu et al., 2013; Lima et al., 2014). On the other hand, the studies that were regarding phenolic compounds and antioxidant properties of sour grape juice were fairly limited.

In the current study, the alterations of phenolic compounds and antioxidant capacity of sour grape juice were investigated during the concentration process stages. The relationship between phenolic content and antioxidant capacity was also observed at six processing stages.

\section{MATERIAL AND METHODS}

\section{Chemicals}

Folin-Ciocalteu reagent, potassium carbonate, formic acid, ethyl alcohol, potassium persulfate were purchased from Merck (Darmstadt, Germany). 2,2diphenyl-1-picrylhydrazyl (DPPH), Trolox (6hydroxy-2,5,7,8-tetramethylchroman-2-carboxylic acid) and methanol were purchased from SigmaAldrich (St. Louis, Missouri, USA). 2,2-azino-bis(3ethylbenzthiazoline- 6-sulfonic acid) (ABTS) was purchased from Amresco Inc. (Radnor, Pennsylvania,
USA). Water for HPLC was purchased from Carlo Erba (Carlo Erba Reagents S.A.S., Val de Reuil, France). Potassium bitartrate $\left(\mathrm{KC}_{4} \mathrm{H}_{5} \mathrm{O}_{6}\right)$ was purchased from Bereket Chemical (Bereket Chemical, ZAG Industry Chemicals, Istambul, Turkey).

Gallic acid, caffeic acid, $p$-coumaric acid, (-)epicatechin and quercetin were purchased form Sigma-Aldrich (St. Louis, Missouri, USA). (+)Catechin, (-)-epigallocatechin gallate, vanilic acid and caftaric acid were purchased from Fluka (St. Louis, MO, USA). (-)-Epigallocatechin and sinapic acid were purchased from Alfa Asear (Karlsruhe, Germany). Ferulic acid was purchased from Merck (Germany).

\section{Sour grapes}

Sour grape samples of Sultani seedless (Vitis vinifera L.) grape variety used for juice production were obtained from Manisa Viticulture Research Institute vineyards. After harvest, samples were immediately transferred to the grape processing unit of the Institute.

Sour grape samples were harvested before veraison period in 2015. No diseases and insect damage were detected in the sour grape samples at harvest; the cluster and berries of sour grapes had good sanitary appearance. The soluble solid value and total acidity of sour grapes were $9.5^{\circ}$ Brix and $30.45 \mathrm{~g} / \mathrm{L}$ (as tartaric acid equivalent), respectively. The $\mathrm{pH}$ value of sour grape was 2.47 .

\section{Sour grape concentrate production}

Sour grapes were rinsed to remove the dust, soil and other impurities after harvest. Then, stalks were discarded and clusters were passed through a crusher destemmer machine (Türköz Metal Makine, Turkey). The mash was pressed in a hydraulic press (Türköz Metal Makine, Turkey) and clear 'koruk' juice was obtained [A]. The juice was kept at $2-4{ }^{\circ} \mathrm{C}$ cold room for $24 \mathrm{~h}$ for precipitation and removing rough residue [B]. Pectolytic enzyme application (Shazym Claro Pectolytic Enzyme, $10.500 \quad$ PGNU/g polygalacturonase, $0.15 \mathrm{~g} / \mathrm{L}$ ) was performed at $50^{\circ} \mathrm{C}$ for $2 \mathrm{~h}[\mathrm{C}]$. Bentonite and gelatin were applied during clarification process; $10 \mathrm{ml} / \mathrm{L}$ from $10 \%$ bentonite solution and $25 \mathrm{ml} / \mathrm{L}$ from $1 \%$ gelatin solution were used at $20^{\circ} \mathrm{C}$ and then 'koruk' juice was kept at $4{ }^{\circ} \mathrm{C}$ for $24 \mathrm{~h}$ [D]. At the same temperature, $5 \mathrm{~g} / \mathrm{L}$ potassium bitartrate $\left(\mathrm{KC}_{4} \mathrm{H}_{5} \mathrm{O}_{6}\right)$ was added and left for 7 days for detartarization [E]. The final clarified 'koruk' juice was concentrated to $42-45^{\circ}$ Brix at 50 ${ }^{\circ} \mathrm{C}$ and $600 \mathrm{~mm} \mathrm{Hg}$ vacuum [F]. Flow diagram of sour grape concentrate production is presented in Figure1. The concentration processing was made in duplicate and $150 \mathrm{~kg}$ of sour grape was used for each replicate. 


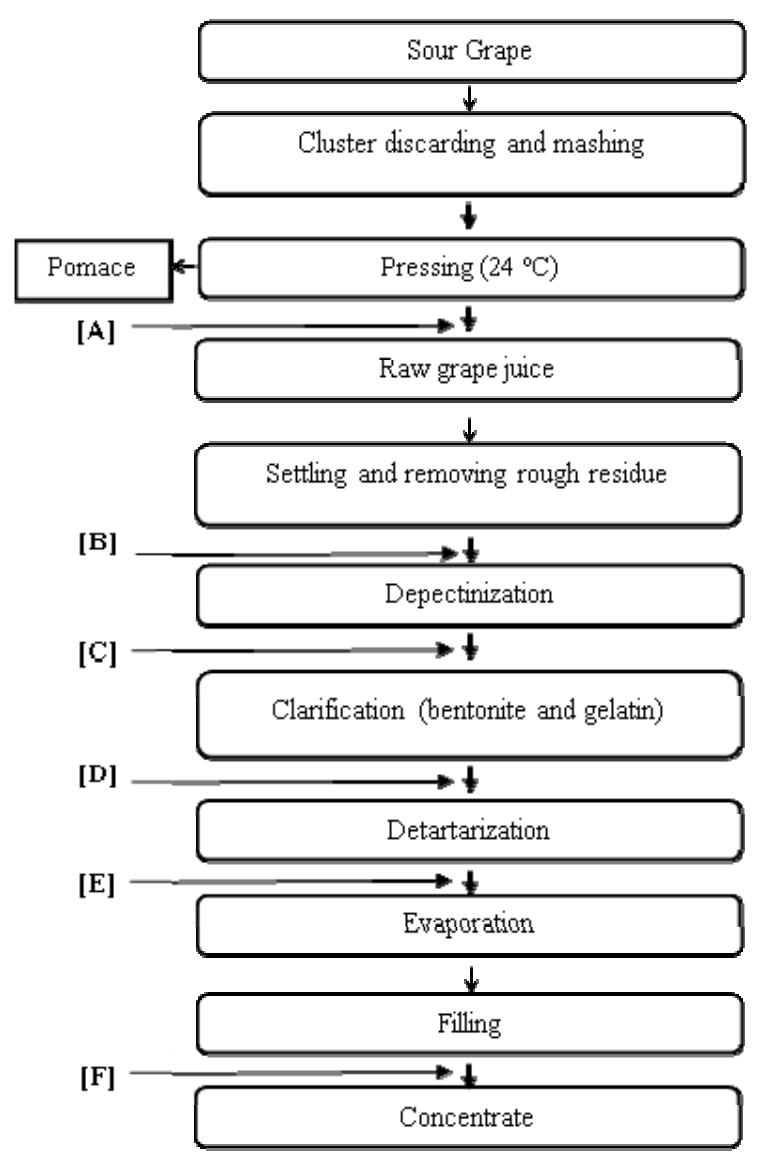

Figure 1. Flow diagram of sour grape concentrate production.

Letters represent the sampling stages: Pressing [A], Removing rough residue [B], Depectinization [C], Clarification [D], Detartarization [E] and Evaporation $[\mathrm{F}]$.

Diagrama da produção do concentrado de sumo de uvas não amadurecidas.

It was chosen six steps for sampling during concentration process. The sampling steps for analysis were at the end of the pressing, removing rough residue, depectinization, clarification, detartarization and evaporation stages. These sampling steps were indicated with $[\mathrm{A}],[\mathrm{B}],[\mathrm{C}],[\mathrm{D}]$, $[\mathrm{E}]$ and $[\mathrm{F}]$ letters, respectively. Six samples were taken from each concentration process steps for analysis.

\section{Determination of total polyphenols}

Total phenolic compounds in the samples were determined according to Folin-Ciocalteu colorimetric method (Singleton and Rossi, 1965). Briefly, $100 \mu \mathrm{L}$ of Folin-Ciocalteu solution was added to each $4 \mathrm{~mL}$ diluted samples and then $500 \mu \mathrm{L}$ of $20 \%$ saturated sodium carbonate $\left(\mathrm{Na}_{2} \mathrm{CO}_{3}\right)$ was added to final solution after $3 \mathrm{~min}$ and all was shaken. Then the samples were incubated at room temperature $(24 \pm 1$ ${ }^{\circ} \mathrm{C}$ ) for $30 \mathrm{~min}$. At the end, $350 \mu \mathrm{L}$ samples were transferred into a 96 well microplate and the absorbance was measured at $760 \mathrm{~nm} .5,10,20,30,40$ and $50 \mathrm{mg} / \mathrm{L}$ of standard concentrations were used for calibration curve $\left(\mathrm{y}=0.0649 \mathrm{x}+0.0324 ; \mathrm{R}^{2}=0.0995\right)$. Results were expressed as milligrams of gallic acid equivalents (GE) in $100 \mathrm{~g}$ dry matter (dry weight, DM).

\section{Radical scavenging activity assay}

2,2-Diphenyl-1-picrylhydrazyl (DPPH) assay was performed according to Brand-Williams et al. (1995). The principle of the method is the measurement of the reduction ability of the DPPH $\bullet$ radical in samples. Briefly, $3 \mathrm{~mL}$ of the $1 \mathrm{mM}$ DPPH solution was transferred into $10 \mathrm{~mL}$ tubes and 200, 400, 600, 800 and $1000 \mu \mathrm{L}$ of diluted samples were added and bring up to $4 \mathrm{~mL}$ with methanol and incubated at room temperature $\left(24 \pm 1^{\circ} \mathrm{C}\right)$ in the dark during $30 \mathrm{~min}$. Methanol was used as blank. The absorbance was measured at $517 \mathrm{~nm}$ wavelength in a spectrophotometer (Thermo scientific, Multiskango, Finland). Percent inhibition values were calculated according to blank absorbance as described in the formula: Inhibition $\%=\left(\left(\mathrm{A}_{\mathrm{DPPH}}-\mathrm{A}_{\mathrm{SAMPLE}}\right) / \mathrm{A}_{\mathrm{DPPH}}\right) \mathrm{x}$ 100. Calculated inhibitions and the sample volumes were subjected to linear regression on the graphic, and slope of each sample and equilibrium of these slopes were obtained. $\mathrm{EC}_{50}$ values were calculated based on the equation of obtained slope values (necessary volume of equate for elimination the $50 \%$ of $\mathrm{DPPH} \bullet): \mathrm{EC}_{50}=[(\mathrm{a} \times$ sample volume $) \pm \mathrm{b}] /$ dilution factor. A calibration curve was drawn using a standard solution of Trolox $(8,16,32,64$ and 128 $\left.\mu \mathrm{M} ; \mathrm{y}=0.2741 \mathrm{x}+0.4972 ; \mathrm{R}^{2}=0.9987\right)$. Antioxidant activity was expressed as $\mu \mathrm{mol}$ Trolox in $100 \mathrm{~g} \mathrm{DM}$.

\section{Trolox equivalent antioxidant capacity assay}

ABTS [2,2'-azinobis-(3-ethylbenzothiazoline-6sulfonic acid)] method was used as previously described by Re et al. (1999). Firstly, stable ABTS stock solution was performed by reacting $7 \mathrm{mM}$ ABTS with $2.45 \mathrm{mM}$ potassium persulfate (final concentration) allowing the mixture to stand in the dark for $12-16 \mathrm{~h}$ at room temperature before use. The ABTS $^{*+}$ solution was diluted with methanol to the absorbance of $0.70 \quad( \pm 0.02)$ at $734 \mathrm{~nm}$ and equilibrated at $30^{\circ} \mathrm{C} .10,20$ and $30 \mu \mathrm{L}$ of each diluted samples were pipetted and $\mathrm{ABTS}^{\circ+}$ radical solution were added to final volume of $1000 \mu \mathrm{L}$. Then, absorbance was measured during $6 \mathrm{~min}$ with one min intervals. The initial $\left(\mathrm{A}_{0}\right)$ and the end of the $6^{\text {th }} \mathrm{min}$ $\left(A_{6}\right)$ absorbance were used for calculation of the absorbance inhibition percentages of each sample or standard volume. 5, 10, 15 and $20 \mu \mathrm{M}$ standard 
Trolox concentration was utilized for calibration curve $\left(y=3.2239 x-0.0101 ; \quad R^{2}=0.9991\right)$. Trolox equivalent antioxidant capacity (TEAC) of the samples was calculated using slope of the sample and standard. Results were expressed as $\mu$ mol Trolox in $100 \mathrm{~g} \mathrm{DM}$.

\section{HPLC analysis for individual phenolic compounds}

Phenolic compounds were evaluated by high performance liquid chromatography (HPLC) method. ODS C18 $(250 \times 4.6 \mathrm{~mm}, 5 \mu \mathrm{m})$ column for analytical separation and diode array detector (DAD) was used in the HPLC system (Agilent 1260 infinity). Detection and quantification of phenolic compounds was carried out according to Ozkan and Gokturk Baydar (2006) and Caponio et al. (1999) with slight modification of mobile phase. $2.5,5,10,20$ and 40 $\mathrm{mg} / \mathrm{L}$ standard concentrations were used for calibration curves of gallic acid, vanillic acid, caftaric acid, caffeic acid, p-coumaric acid, ferulic acid, sinapic acid, quercetin and (-)-epicatechin. 5, 10, 20, 40 and $60 \mathrm{mg} / \mathrm{L}$ concentrations were used for $(+)-$ catechin, (-)-epigallocatechin and (-)-epigallocatechin gallate calibration curves. The sour grape juice samples taken from the previously defined steps were diluted with methanol and filtered through a $0.45 \mu \mathrm{m}$ of PTFE syringe filter before the HPLC analysis. Then, the samples were injected directly into the HPLC system.

Gradient elution was used; solvents consisting of ultra-pure water: formic acid (99.8:0.2 v/v) (A) and methanol (B). Gradient elution program was as follows: the initial elution $0 \% \mathrm{~B}$, followed $3 \mathrm{~min}$ by linear gradient from $0 \%$ to $5 \% \mathrm{~B}, 15$ min linear gradient to $20 \% \mathrm{~B}, 2 \mathrm{~min}$ isocratic elution step $\% 20$ $\mathrm{B}, 10$ min linear gradient elution to $25 \% \mathrm{~B}, 10 \mathrm{~min}$ elution to $30 \% \mathrm{~B}, 10 \mathrm{~min}$ elution to $40 \% \mathrm{~B}, 5 \mathrm{~min}$ elution to $50 \% \mathrm{~B}$ and 10 min linear gradient elution to $100 \% \mathrm{~B}$. Then, 5 min $100 \%$ A elution was performed for returning to initial condition. Column temperature was set at $30^{\circ} \mathrm{C}$ and detection was made at 280,320 and $360 \mathrm{~nm}$. Gallic acid, (+)-catechin, (-)epigallocatechin, vanillic acid, (-)-epigallocatechin gallate and (-)-epicatechin were detected at $280 \mathrm{~nm}$ wavelength. Caftaric acid, caffeic acid, p-coumaric acid, ferulic acid and sinapic acid were identified at $320 \mathrm{~nm}$. Finally, quercetin was detected at $360 \mathrm{~nm}$ wavelength. The elution time was $65 \mathrm{~min}$, the injection volume was $10 \mu \mathrm{L}$ and the flow rate was $1 \mathrm{~mL} / \mathrm{min}$. The phenolic compounds of the samples were identified by comparing their retention times and spectra with those of analytical standards. The concentration of phenolic compounds in the samples was calculated through the calibration curves and expressed as mg/100 g DM. Chromatographic analyses were performed in triplicate.

\section{Statistical analysis}

A two-way analysis of variance (ANOVA) was applied to the obtained results. Duncan multiple comparison test was performed to determine the differences between the average values $(p<0.05$ significance level was used for comparisons). Pearson correlation coefficients were calculated to prove the relationships between total phenolics and antioxidant properties.

\section{RESULTS AND DISCUSSION}

The results for total phenolic (TP) contents of the samples are presented in Table I, where it can be observed that the values varied from 245.62 and $288.4 \mathrm{mg} / 100 \mathrm{~g} \mathrm{DM}$ at processing steps. Significant statistical differences were found between the TP values of the investigated processing steps $(\mathrm{p}<0.05)$. The lowest TP content was found in [F] stage (after evaporation), while the highest TP was found in [A] stage. According to Piva et al. (2008), which investigated the physical and functional alterations during grape juice cooking using three different concentrate ratios (max. 35, 60 and $70 \%$ ), the TP contents in fresh and concentrated grape must samples varied from 27.1 to $1259 \mathrm{mg} / \mathrm{L}$. Öncül and Karabiyıkl1 (2015) reported that TP content of 'verjuice' samples varied from 233.44 and 672.75 mg/L. Nikfardjam (2008) reported similar TP content ranges in 'verjuice' (200-1330 mg/L). Turkmen et al. (2017) revealed that TP contents of unripe grape juice extracts ranged from 436.36 and $758.52 \mathrm{mg} / \mathrm{L}$. Hayoglu et al. (2009) reported that TP content of 'verjuice' samples ranged from 2374.8 to 4041.5 $\mathrm{mg} / \mathrm{L}$. TP results of the sour grape concentrate are similar to those obtained in previous studies. However, the results are lower than the results reported by Hayoglu et al. (2009). The differences could be due to the maturation of grape, applied process steps and evaporation conditions (Gollücke et al., 2009; Hayoglu et al., 2009; Sabir et al., 2010; Öncül and Karabıyıklı, 2015; Tastan and Baysal, 2015).

TP content of the concentrate decreased approximately $14.8 \%$ according to the first processing stage. The decreasing was linear from $[\mathrm{A}]$ to $[\mathrm{F}]$ stages. Gollücke et al. (2009) reported that TP contents of 'Concord' and 'Isabel' grape juice concentrate decreased after heat treatment and the reduction was lower than after filtration and concentration. 
TABLE I

Total phenolic content and antioxidant properties of sour grape processing samples

Teor total de compostos fenólicos e atividades antioxidantes das amostras de sumo de uvas não amadurecidas recolhidas durante o processamento

\begin{tabular}{|c|c|c|c|c|c|c|}
\hline Process steps & $\begin{array}{c}{ }^{* *} \mathrm{TP} \\
(\mathrm{mg} / 100 \mathrm{~g} \mathrm{DM})\end{array}$ & $\begin{array}{c}* * \mathbf{D P P H}_{\mathrm{inh}} \\
(\%)\end{array}$ & $\begin{array}{l}* * \mathbf{D P P H} \\
\mathrm{EC}_{50}(\mu \mathrm{l})\end{array}$ & $\begin{array}{c}* * \text { TEAC } \\
(\mu \mathrm{mol} / 100 \mathrm{~g} \mathrm{DM})\end{array}$ & $\begin{array}{c}* * \mathbf{A B T S}_{\mathrm{inh}} \\
(\%)\end{array}$ & $\begin{array}{c}* * \text { TEAC }_{\mathrm{ABTS}} \\
(\mu \mathrm{mol} / 100 \mathrm{~g} \mathrm{DM})\end{array}$ \\
\hline Pressing $[\mathrm{A}]$ & $288.42 \pm 6.23^{\mathrm{a}}$ & $20.62 \pm 1.45^{\mathrm{c}}$ & $198.00 \pm 0.82^{b}$ & $569.25 \pm 21.86^{\mathrm{c}}$ & $20.44 \pm 0.01^{\mathrm{d}}$ & $1369.78 \pm 8.61^{\mathrm{d}}$ \\
\hline Removig Rough Residue [B] & $274.81 \pm 2.66^{\mathrm{b}}$ & $18.11 \pm 2.28^{\mathrm{c}}$ & $264.59 \pm 7.44^{\mathrm{a}}$ & $675.17 \pm 28.16^{\mathrm{ab}}$ & $24.53 \pm 0.86^{\mathrm{c}}$ & $1672.00 \pm 10.57^{\mathrm{a}}$ \\
\hline Depectinization $[\mathrm{C}]$ & $277.68 \pm 3.52^{b}$ & $22.73 \pm 1.64^{\mathrm{bc}}$ & $165.91 \pm 1.97^{\mathrm{c}}$ & $698.79 \pm 15.39^{\mathrm{ab}}$ & $26.63 \pm 0.30^{b}$ & $1461.82 \pm 8.39^{\mathrm{c}}$ \\
\hline Clarification [D] & $259.42 \pm 0.41^{\mathrm{c}}$ & $19.35 \pm 0.71^{\mathrm{c}}$ & $204.07 \pm .163^{b}$ & $728.74 \pm 22.80^{\mathrm{a}}$ & $19.01 \pm 0.70^{\mathrm{d}}$ & $1521.89 \pm 48.80^{\mathrm{b}}$ \\
\hline Detartarization [E] & $256.89 \pm 0.82^{\mathrm{c}}$ & $25.64 \pm 0.34^{\mathrm{b}}$ & $198.24 \pm 1.42^{b}$ & $652.10 \pm 43.47^{\mathrm{b}}$ & $26.91 \pm 0.20^{\mathrm{b}}$ & $1380.39 \pm 4.13^{\mathrm{d}}$ \\
\hline Evaporation [F] & $245.62 \pm 4.34^{\mathrm{d}}$ & $80.78 \pm 3.70^{\mathrm{a}}$ & $30.68 \pm 0.47^{\mathrm{d}}$ & $488.59 \pm 19.56^{d}$ & $69.38 \pm 1.30^{\mathrm{a}}$ & $1137.22 \pm 4.82^{\mathrm{e}}$ \\
\hline
\end{tabular}

On the other hand, Capanoglu et al. (2013) investigated the changes of polyphenols during production of grape juice concentrate and stated that TP content of grape concentrate decreased by $84.4 \%$ dry weight basis. The ratio is considerably higher than in the current study.

Antioxidant activities of samples were detected by DPPH and ABTS assays and the obtained results were showed in Table I. Significant statistical differences were observed among processing steps for all antioxidant properties evaluated $(\mathrm{p}<0.05)$. DPPH and ABTS inhibitions in [A] stage (after pressing) were 20.62 and $20.44 \%$; the inhibitions in [F] stage (after evaporation) were 80.78 and $69.68 \%$, respectively. Turkmen et al. (2017) found that DPPH inhibitions of unripe grape juice samples varied between 64.07 and $82.64 \%$.

$\mathrm{TEAC}_{\mathrm{ABTS}}$ and $\mathrm{TEAC}_{\mathrm{DPPH}}$ of the samples ranged from 1137.22 to $1672.00 \mu \mathrm{mol} / 100 \mathrm{~g} \mathrm{DM}$ and from 488.59 to $698.79 \mu \mathrm{mol} / 100 \mathrm{~g} \mathrm{DM}$, respectively. Antioxidant activity of 'verjuice' samples were reported as 25-231 $\mu \mathrm{mol} \mathrm{TE} / \mathrm{L}$ for FRAP and 158-885 $\mu \mathrm{mol} \mathrm{TE} / \mathrm{L}$ for TEAC by Öncül and Karabıyıklı (2015). Additionally, in the same study, the values in 'verjuice' sauces were between 35 and $721 \mu \mathrm{mol}$ TE/L for TEAC.

The changes of antioxidant activities during concentrate processing are presented in Figure 2. $\mathrm{TEAC}_{\mathrm{DPPH}}$ and $\mathrm{TEAC}_{\mathrm{ABTS}}$ values in the samples increased compared to $[\mathrm{A}]$ stage at $[\mathrm{B}],[\mathrm{C}]$ and $[\mathrm{D}]$ processing stages. The increase varied between 14.58 and $28.12 \%$ for $\mathrm{TEAC}_{\mathrm{DPPH}}$ and 0.72 to $18.06 \%$ for $\mathrm{TEAC}_{\mathrm{ABTS}}$. After [D] stage, antioxidant activity started to decrease. The lowest antioxidant activity results were found in $[\mathrm{F}]$ stage. After evaporation $[\mathrm{F}]$, the $\mathrm{TEAC}_{\mathrm{DPPH}}$ and $\mathrm{TEAC}_{\mathrm{ABTS}}$ values decreased 14.2 and $17.0 \%$ compared to [A] stage, respectively.

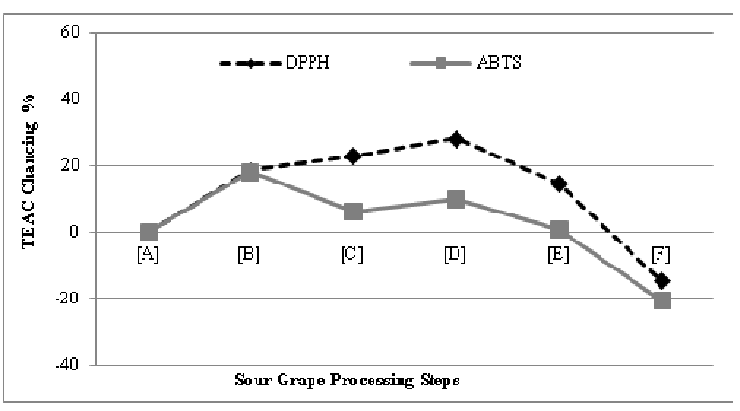

Figure 2. TEAC changing during sour grape processing.

Alteração de TEAC durante o processamento do sumo de uvas não amadurecidas.

Piva et al. (2008) reported that antioxidant activities of fresh and concentrated grape juice samples varied from 925 to $2100 \mu \mathrm{M} / \mathrm{L}$. They concentrated the grape juice until 35, 60 and $70 \%$ ratios. The antioxidant activities in grape must concentrates decreased compared to initial fresh must values in dry weight bases. The reduction was 24.7 and $27.0 \%$ for 60 and $70 \%$ concentration ratios, respectively (Piva et al., 2008). It was reported that the antioxidant activity of the grape juice concentrate decreased between 83 and $92 \%$ during concentration stages compared to the 
initial stage. The reduction ratios from pasteurization to concentration stages were 3.6 and $10.4 \%$ for ABTS and DPPH methods, respectively. Moreover, it was expressed that antioxidant capacity showed some variation through the concentration process of grape juice (Gollucke et al., 2009). The current findings obtained from the sour grape concentrate have slightly differences with those of previous studies. These differences could be due to the maturity of the grapes because sour grapes are unripe grapes and they have different chemical and physical characteristics comparing to mature grapes. Öncül and Karabiyıklı (2015) have also reported the change of antioxidant components in grape depending on maturation. Additionally, grape varieties, heat treatment in processing and other processing conditions may affect these parameters.

Correlations between TP and antioxidant parameters in the sour grape concentration process are shown in
Table II. Significant correlations were found among $\mathrm{TP}$, inhibitions of $\mathrm{DPPH}$ and $\mathrm{ABTS}, \mathrm{EC}_{50}$ and $\mathrm{TEAC}_{\mathrm{ABTS}}$ and $\mathrm{TEAC}_{\mathrm{DPPH}} \quad(\mathrm{p}<0.01)$. The highest positive and the most significant correlation was observed between TP and $\mathrm{TEAC}_{\mathrm{ABTS}}(\mathrm{r}=0.999$, $\mathrm{p}<0.01)$. The negative significant correlation was found between TP and $\mathrm{EC}_{50}(\mathrm{r}=-0.919, \mathrm{p}<0.01)$. Additionally, important correlations were obtained between DPPH and ABTS parameters. Lima et al. (2014) found that the correlations between the total phenolic contents and the DPPH and ABTS antioxidant activities in grape juice samples were 0.94 and 0.84 , respectively. In other study, Burin et al. (2010) reported the positive correlations found between total phenolic content and antioxidant activity (DPPH methods) of grape juice samples. Öncül and Karabıyıklı (2015) have also showed similar correlation results. The correlations between TP and antioxidant parameters are consistent with the literature.

TABLE II

Correlations of between total phenolic compounds and antioxidant properties in the sour grape concentrate

Correlações entre o teor total de compostos fenólicos e as atividades antioxidantes do concentrado de sumo de uvas não amadurecidas

\begin{tabular}{|c|c|c|c|c|c|c|}
\hline $\mathbf{T P}$ & 1 & 0.994 & -0.919 & 0.998 & 0.991 & 0.999 \\
\hline $\mathbf{D P P H}_{\mathrm{inh}}$ & 0.994 & 1 & -0.929 & 0.992 & 0.989 & 0.992 \\
\hline DPPH EC 50 & -0.919 & -0.929 & 1 & -0.921 & 0.905 & -0.911 \\
\hline $\mathbf{A B T S}_{\mathrm{inh}}$ & 0.991 & 0.989 & 0.905 & 0.986 & 1 & 0.992 \\
\hline TEAC $_{\text {ABTS }}$ & 0.999 & 0.992 & -0.911 & 0.998 & 0.992 & 1 \\
\hline
\end{tabular}

Inhibition value for ABTS method; TEAC: Trolox equivalent antioxidant capacity.

The values of the 12 phenolic compounds studied during sour grape processing stages are presented in Table III. The HPLC chromatogram obtained for the sour grape juice concentrate of the 12 investigated phenolic compounds is shown in Figure 3. Regarding individual phenolic compounds, caftaric acid was the major compound, with values varying from 12.40 to $37.60 \mathrm{mg} / 100 \mathrm{~g}$ in sour grape juice samples during the concentrate processing. In a study that have investigated phenolic compounds in 'verjuice' samples from different countries also mentioned the caftaric acid, whose ranged from 15.6 to $76.3 \mathrm{mg} / \mathrm{L}$, as the main phenolic compound (Nikdardjam, 2008). Additionally, it was reported that caftaric acid was the major phenolic substance in the grape juice and wine (Toaldo et al., 2015; Yamamoto et al., 2015, Padilha et al., 2017; Aleixandre-Tudo et al., 2018). The caftaric acid values in these studies varied from 73.4 to $365.5 \mathrm{mg} / \mathrm{L}$ in grape juices and 6.6 to $167.4 \mathrm{mg} / \mathrm{L}$ in wines. The findings related to caftaric acid in the current study are accordance with these literature's results.

The contents of gallic, vanillic, caffeic and $p$ coumaric acids during the sour grape processing stages ranged from 1.05 to $1.83 \mathrm{mg} / 100 \mathrm{~g}, 3.01$ to $5.18 \mathrm{mg} / 100 \mathrm{~g}, 1.44$ to $2.26 \mathrm{mg} / 100 \mathrm{~g}$ and 0.27 to $0.44 \mathrm{mg} / 100 \mathrm{~g}$, respectively. Ferulic acid, sinapic acid and quercetin were detected only at $[\mathrm{F}]$ step of sour grape juice processing and their contents were 0.18 $\mathrm{mg} / 100 \mathrm{~g}, 0.28 \mathrm{mg} / 100 \mathrm{~g}$ and $0.76 \mathrm{mg} / 100 \mathrm{~g}$, respectively. (-)-Epigallocatechin gallate results in the samples varied from and 0.76 to $1.95 \mathrm{mg} / 100 \mathrm{~g}$. 
TABLE III

Phenolic compounds contents in sour grape processing stages

Teores de compostos fenólicos nas etapas do processo de concentração do sumo de uvas não amadurecidas

\begin{tabular}{|c|c|c|c|c|c|c|}
\hline \multirow[b]{2}{*}{ Phenolics (mg/100 g DM) } & \multicolumn{6}{|c|}{ Sour Grape Processing Stages } \\
\hline & $\begin{array}{l}\text { Pressing } \\
{[\text { [A] }}\end{array}$ & $\begin{array}{c}\text { Removig Rough Residue } \\
{[\mathrm{B}]}\end{array}$ & $\begin{array}{l}\text { Depectinization } \\
{[[C]}\end{array}$ & $\begin{array}{c}\text { Clarification } \\
\text { [D] }\end{array}$ & $\begin{array}{c}\text { Detartarization } \\
{[\mathbf{E}]}\end{array}$ & $\begin{array}{c}\text { Evaporation } \\
{[\text { F }]}\end{array}$ \\
\hline Gallic acid & $1.31 \pm 0,06^{\mathrm{d}}$ & $1.83 \pm 0.02^{\mathrm{a}}$ & $1.05 \pm 0,06^{\mathrm{e}}$ & $1.73 \pm 0,01^{\mathrm{b}}$ & $1.56 \pm 0.01^{\mathrm{c}}$ & $1.76 \pm 0.01^{\mathrm{ab}}$ \\
\hline Vanilic acid & $3.05 \pm 0.01^{\mathrm{b}}$ & $3.01 \pm 0.59^{\mathrm{b}}$ & $3.16 \pm 0.18^{\mathrm{b}}$ & $4.88 \pm 0.07^{\mathrm{a}}$ & $5.00 \pm 0.05^{\mathrm{a}}$ & $5.18 \pm 0.03^{\mathrm{a}}$ \\
\hline Caftaric acid & $30.55 \pm 0.26^{\mathrm{b}}$ & $37.60 \pm 0.28^{\mathrm{a}}$ & $14.15 \pm 0.10^{\mathrm{e}}$ & $12.40 \pm 0.10^{\mathrm{f}}$ & $16.97 \pm 0,16^{\mathrm{c}}$ & $14.98 \pm 0.22^{\mathrm{d}}$ \\
\hline Caffeic acid & $2.26 \pm 0.03^{\mathrm{a}}$ & $2.11 \pm 0.19^{\mathrm{a}}$ & $1.60 \pm 0.05^{\mathrm{b}}$ & $1.58 \pm 0.14^{\mathrm{b}}$ & $1.70 \pm 0.02^{\mathrm{b}}$ & $1.44 \pm 0.03^{\mathrm{b}}$ \\
\hline$p$-coumaric acid & $0.32 \pm 0.01^{\mathrm{bc}}$ & $0.33 \pm 0.02^{\mathrm{b}}$ & $0.32 \pm 0.01^{\mathrm{bc}}$ & $0.40 \pm 0.02^{\mathrm{a}}$ & $0.44 \pm 0.05^{\mathrm{a}}$ & $0.27 \pm 0.02^{\mathrm{c}}$ \\
\hline Ferulic acid & n.d. & n.d. & n.d. & n.d. & n.d. & $0.18 \pm 0.01$ \\
\hline Sinapic acid & n.d. & n.d. & n.d. & n.d. & n.d. & $0.28 \pm 0.02$ \\
\hline$(+)$-Catechin & $5.96 \pm 1.50$ & $6.94 \pm 0.94$ & $6.53 \pm 0.10$ & $7.82 \pm 0.16$ & $7.83 \pm 0.13$ & $5.40 \pm 0.04$ \\
\hline (-)-Epigallocatechin & $6.35 \pm 0.66$ & $8.03 \pm 0.49$ & $7.08 \pm 1.73$ & $6.81 \pm 0.09$ & $7.22 \pm 0.07$ & $9.21 \pm 0.20$ \\
\hline (-)-Epigallocatechin gallate & $1.95 \pm 0.01$ & $1.52 \pm 0.02$ & n.d. & n.d. & n.d. & $0.76 \pm 0.09$ \\
\hline (-)-Epicatechin & $2.79 \pm 0,33^{\mathrm{cd}}$ & $3.00 \pm 0,03^{\mathrm{bc}}$ & $3.54 \pm 0,22^{\mathrm{a}}$ & $3.24 \pm 0,24^{\mathrm{abc}}$ & $3.43 \pm 0,08^{\mathrm{ab}}$ & $2.33 \pm 0,42^{\mathrm{d}}$ \\
\hline Quercetin & n.d. & n.d. & n.d. & n.d. & n.d. & $0.76 \pm 0.06$ \\
\hline
\end{tabular}

$(+)$-Catechin and (-)-epigallocatechin values were found between 5.40 and $7.83 \mathrm{mg} / 100 \mathrm{~g}$ and 6.35 and $9.21 \mathrm{mg} / 100 \mathrm{~g}$ in the samples, respectively. No statistical differences were observed for catechin and (-)-epigallocatechin values among the processing stages. Statistical differences were observed for all the evaluated phenolic compounds, except ferulic acid, sinapic acid and quercetin among the processing steps $(p<0.05)$. Since $(-)$-epigallocatechin gallate, ferulic acid, sinapic acid and quercetin were no detected in the samples collected at some processing stages, the corresponding statistical analysis was no performed.

The average contents of the (+)-catechin, (-)epicatechin, quercetin, gallic, caffeic and $p$-coumaric acids were $2.1-21.3 \mathrm{mg} / \mathrm{L}, 0.4-4.0 \mathrm{mg} / \mathrm{L}, 0.1 \mathrm{mg} / \mathrm{L}$, $36.6-70.6 \mathrm{mg} / \mathrm{L}, 6.6-19.8 \mathrm{mg} / \mathrm{L}$ and $1.8-2.1 \mathrm{mg} / \mathrm{L}$

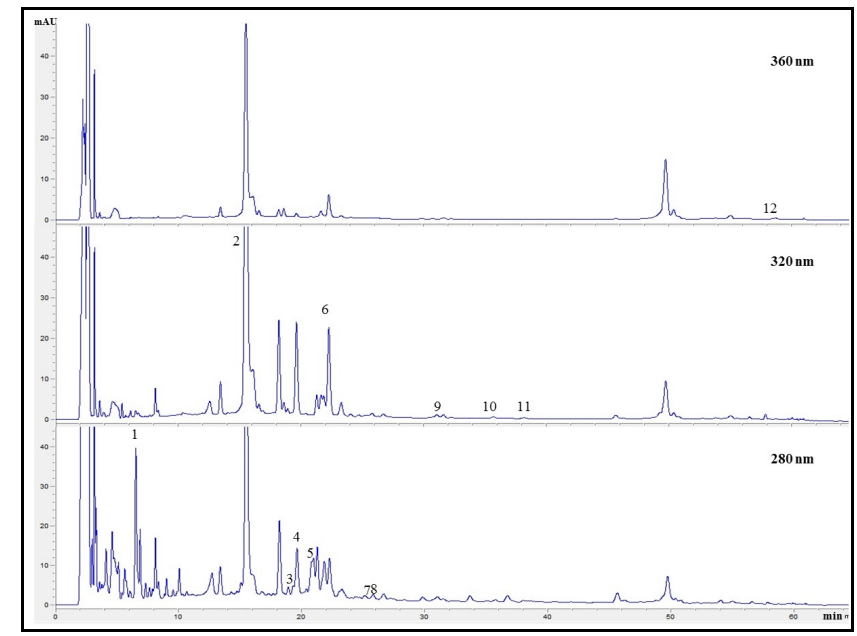

Figure 3. HPLC-DAD chromatogram of the phenolic compounds of the sour grape concentrate.

1: Gallic acid; 2: Caftaric acid; 3: (+)-Catechin; 4: (-)-Epigallocatechin; 5: Vanillic acid; 6: Caffeic acid; 7: (-)-Epigallocatechin gallate; 8: (-)Epicatechin; 9: $p$-coumaric acid; 10: Ferulic acid; 11: Sinapic acid; 12: Quercetin.

Cromatograma HPLC-DAD dos compostos fenólicos no concentrado de sumo de uvas não amadurecidas. 
in the 'verjuice' samples and from 2.20 to 500.52 $\mathrm{mg} / \mathrm{L}, 0.6$ to $10.84 \mathrm{mg} / \mathrm{L}, 0.04$ to $4.27 \mathrm{mg} / \mathrm{L}, 1.8$ to $16.96 \mathrm{mg} / \mathrm{L}, 1.43$ to $41.2 \mathrm{mg} / \mathrm{L}$ and 0.07 to 11.23 $\mathrm{mg} / \mathrm{L}$ in the grape juice samples according to literature (Nikdardjam, 2008; Natividade et al., 2013; Lima et al., 2014; Toaldo et al., 2015; Yamamoto et al., 2015; Margraf et al., 2016; Padilha et al., 2017; Cosme et al., 2018). Moreover, it is reported that (-)epigallocatechin gallate, (-)-epigallocatechin, ferulic acid, sinapic acid and vanillic acid are from 0.60 to $6.20 \mathrm{mg} / \mathrm{L}, 0.9$ to $368.2 \mathrm{mg} / \mathrm{L}, 0.15$ to $5.20 \mathrm{mg} / \mathrm{L}, 0.4$ to $2.8 \mathrm{mg} / \mathrm{L}$ and 20.00 to $444.92 \mathrm{mg} / \mathrm{L}$ in the grape juices which produced in Brazil (Natividade et al., 2013; Lima et al., 2014; Toaldo et al., 2015).

The contents detected for gallic, caffeic and pcoumaric acids in the current work are lower than those found by Nikdardjam (2008), but (+)-catechin and (-)-epicatechin values are in accordance with the previous findings. The results for $(+)$-catechin, (-)epicatechin, gallic, caffeic and $p$-coumaric acids are in accordance with the results of previous studies (Natividade et al., 2013; Lima et al., 2014; Toaldo et al., 2015; Yamamoto et al., 2015; Margraf et al., 2016; Padilha et al., 2017; Cosme et al., 2018).

(-)-Epigallocatechin gallate is an important substance for human health. In a study; Legeay et al. (2015) investigated the beneficial properties of (-)epigallocatechin gallate to prevent metabolic syndrome. Additionally, it has reported that (-)epigallocatechin gallate has higher antioxidant capacity than other catechins (Rice-Evans, 1999; Legeay et al., 2015). Natividade et al. (2013) stated

\section{REFERENCES}

Aleixandre-Tudo J.L., Nieuwoudht H., Olivieri A., Aleixandre J.L., Toit W., 2018. Phenolic profiling of grapes, fermenting samples and wines using UV-visible spectroscopy with chemometrics. Food Control, 85, 11-22.

Brand-Williams W., Cuvelier M.E., Berset C., 1995. Use of free radical method to evaluate antioxidant activity. Lebensm. Wiss. Technol., 28, 25-30.

Burin V.M., Falcao L.D., Gonzaga R.F., Rosier J.P., BordignonLuiz M.T., 2010. Colour, phenolic content and antioxidant activity of grape juice. Ciênc. Tecnol. Aliment., 30, 1027-1032.

Büyüktuncel E., Porgalı E., Çolak C., 2014. Comparison of total phenolic content and total antioxidant activity in local red wines determined by spectrophotometric methods. Food Nutr. Sci., 5, 1660-1667.

Capanoglu E., de Vos R.C.H., Hall R.D, Boyacioglu D., Beekwilder B., 2013. Changes in polyphenol content during production of grape juice concentrate. Food Chem., 139, 521-526.

Caponio F., Alloggio V., Gomes, T., 1999. Phenolic compounds of virgin olive oil: influence of paste preparation techniques. Food Chem., 64, 203-209. that (-)-epigallocatechin gallate average content in Vitis Labrusca ('Isabel Precoce'), hybrid (BRS Cora and BRS Violeta) and Vitis vinifera ('Tempranillo', 'Syrah', 'Alicante Bouschet' and 'Moscato Canneli') grape juices are $0.63-6.20 \mathrm{mg} / \mathrm{L}, 1.77 \mathrm{mg} / \mathrm{L}$ and 0.60 $2.39 \mathrm{mg} / \mathrm{L}$, respectively. In the current study, changes found for (-)-epigallocatechin gallate during processing stages were from 0.76 to $1.95 \mathrm{mg} / 100 \mathrm{~g}$ and the contents are in accordance with the mentioned literature (Natividade et al., 2013). On the other hand, this compound was not detected at [C], [D] and [E] processing stages.

\section{CONCLUSIONS}

Changes in the phenolic profile of the sour grape juice were evaluated during the concentrate processing stages. In addition, the antioxidant activities were analyzed with DPPH and ABTS methods. It was found that concentration process affects phenolic compounds, antioxidant capacity and correlation among these parameters. Especially, total phenolic content and antioxidant properties of the samples changed at the evaporation stage more than in the other processing stages. After evaporation under vacuum conditions, antioxidant activity of the samples decreased approximately between 14.2 and $17.0 \%$ for DPPH and ABTS methods, respectively. Besides, TP content of the samples also decreased approximately $14.8 \%$ according to [A] processing stage.

Castilla P., Echarri R., Davalos A., Cerreato F., Ortega H., Teruel J.L., 2006. Concentrated red grape juice exerts antioxidant, hypopolipidemic, and anti-inflammatory effects in both hemodialysis patients and health subjects. Am. J. Clin. Nutr., 84, 252- 2652 .

Chira K., Suh J.H., Saucier C., Teissèdre P.L., 2008. Les polyphénols du raisin. Phytothérapie, 6, 75-82.

Cosme F., Pinto T., Vilela A., 2018. Phenolic Compounds and antioxidant activity in grape juices: A chemical and sensory view. Beverages, 4, 3-14.

Falchi M., Bertelli, A., Scalzo R.L., Morassut M., Morelli R., Das S., Cui J.H., Das,D.K., 2006. Comparison of cardioprotective abilities between the flesh and skin of grapes. J. Agric. Food Chem., 54, 6613-6622.

God J.M., Tate P., Larcom L.L., 2007. Anticancer effects of four varieties of muscadine grape. J. Med. Food., 10, 54-59.

Gollucke A.P.B., Catharino R.R., De Souza J.C., Eberlin M.N., Tavares D.Q., 2009. Evolution of major phenolic components and radical scavenging activity of grape juices through concentration process and storage. Food Chem., 112, 868-873.

Hayoglu I., Kola O., Kaya C., Özer S., Türkoğlu H., 2009. Chemical and sensory properties of verjuice, a traditional Turkish 
non-fermented beverage from Kabarcik and Yediiveren grapes. $J$. Food. Process. Pres., 33, 252-263.

Karapinar M., Sengun I.Y., 2007. Antimicrobial effect of koruk (unripe 258 grape-Vitis vinifera) juice against Salmonella typhimurium on salad vegetables. Food Control, 18, 702-706.

Legeay S., Rodier M., Fillon L., Faure S., Clere, N., 2015., Epigallocatechin gallate: A review of its beneficial properties to prevent metabolic syndrome. Nutrients, 7, 5443-5468.

Lima M.S., Silani I.S.V., Toaldo I.M.T., Corrêa L.C., Biasoto A.C.T., Pereira G.E., Bordignon-Luiz MT, Ninow JL., 2014. Phenolic compounds, organic acids and antioxidant activity of grape juices produced from new Brazilian varieties planted in the Northeast Region of Brazil. Food Chem., 16, 194-103.

Margraf T., Santos E.N.T., Andrade E.E., Ruth S.M., Granato, D., 2016. Effects of geographical origin, variety and farming system on the chemical markers and in vitro antioxidant capacity of Brazilian purple grape juices. Food Res. Int., 82, 145-155.

Meyer A.S., Yi O.S., Pearson D.A., Waterhouse A.L., Frankel E.N., 1997. Inhibition of human low density lipoprotein oxidation in relation to composition of phenolic antioxidants in grapes (Vitis vinifera). J. Agric. Food Chem., 45, 1638-1643.

Natividade, M.M.P., Correa L.C., Souza S.V.C., Pereira G.E., Lima L.C.O., 2013. Simultaneous analysis of 25 phenolic compounds in grape juice for HPLC: Method validation and characterization of São Francisco Valley samples. Microchem J., 110, 665-674.

Nickfardjam M.S.P., 2008. General and polyphenolic composition of unripe grape juice (verjus/verjuice) from varius producers. Mitt. Klosterneuburg., 58, 28-31.

Öncül N., Karabıyıklı Ş., 2015. Factors affecting the quality attributes of unripe grape functional food products. J. Food Biochem., 39, 689-695.

Ozkan G., Gokturk Baydar N., 2006. A direct RP-HPLC determination of phenolic compounds in Turkish red wines. Akdeniz University Journal of the Faculty of Agriculture, 19, 229234.

Padilha, C.V.S., Miskiniz, G.A., Souza M.E.A.O., Pereira, G.E., Oliveira D., Bordignon-Luiz M.T., Lima M.S., 2017. Rapid determination of flavonoids and phenolic acids in grape juices and wines by RP-HPLC/DAD: Method validation and characterization of commercial products of the new Brazilian varieties of grape. Food Chem., 228, 106-115.

Paixao N., Perestrelo R., Marques J.C., Câmara J.S., 2007. Relationship between antioxidant capacity and total phenolic content of red, rosé and white wines. Food Chem., 105, 204- 214.

Piva A., Di Mattia C., Neri .L, Dimitri G., Chiarini M., Sacchetti G., 2008. Heat-induced chemical, physical and functional changes during grape must cooking. Food Chem., 106, 1057-1065.
Re R., Pellegrini N., Proteggente A., Pannala A., Yang M., RiceEvans C., 1999. Antioxidant activity applying an improved ABTS radical cation decolorization assay. Free Radic. Biol. Med., 26, 1231-1237.

Rice-Evans C., 1999. Implications of the mechanisms of action of tea polyphenols as antioxidants in vitro for chemoprevention in humans. Proc. Soc. Exp. Biol. Med., 220, 262-266.

Sabir A., Kafkas E., Tangolar S., 2010. Distribution of major sugars, acids and total phenols in juice of five grapevine (Vitis spp.) cultivars at different stages of berry development. Span. J. Agric. Res., 8, 425-433.

Singleton V.L., Rossi J.R., 1965. Colorimetry of total phenolics with Phospho molybdic phosphotungstic acid. Am. J. Enol. Vitic., 16, 144-158.

Stratil P., Kuban V., Fojtova J., 2008. Comparison of the phenolic 285 content and total antioxidant activity in wines as determined by spectrophotometric methods. Czech J. Food Sci., 26(4), 242-253.

Tastan O., Baysal T., 2015. Clarification of pomegranate juice with chitosan: Changes on quality characteristics during storage. Food Chem., 180, 211-218.

Toaldo I.M., Fernanda A.C., Alves T.L., Gois J.S., Borges D.L.G., Cunha H.P., Silva E.L., Bordignon-Luiz M.T., 2015. Bioactive potential of Vitis labrusca L. grape juices from theSouthern Region of Brazil: phenolic and elemental composition and effect on lipid peroxidation in healthy subjects. Food Chem., 173, 527- 535.

Tsanga C., Higginsa S., Duthiea G.G., Duthiea S.J., Howiea M., Mullena W., Leana M.E.J., Crozier A., 2005. The influence of moderate red wine consumption on antioxidant status and indices ofoxidative stress associated with CHD in healthy volunteers. $B r . J$. Nutr., 93, 233-240.

Turkmen F.U., Takci H.A., Sekeroglu N., 2017. Total phenolic and flavonoid contents, antioxidant and antimicrobial activities of traditional unripe grape products. Indian J. Pharm. Educ., 51, 489493.

Xia E.Q., Deng G.F., Guo Y.J., Li H.B., 2010. Biological activities of polyphenols from grapes. Int. J. Mol. Sci., 11, 622-646.

Yamamoto L.Y., Assis A.M., Roberto S.R., Bovolenta Y.R., Nixdorf S.L., García-Romero E., Gómez-Alonso S., HermosínGutiérrez I., 2015. Application of abscisic acid (S-ABA) to cv. Isabel grapes (Vitis vinifera $\times$ Vitis labrusca) for color improvement: Effects on color, phenolic composition and antioxidant capacity of their grape juice. Food Res. Int., 77, 572583.

ZibaeeNezhad M.J., Mohammadi E., Beigi M.A.B., Mirzamohammadi F., Salehi O., 2012. The effects of unripe grape juice on lipid profile improvement. Hindawi Publishing Corporation Cholesterol, 2012, 1-3. 